\title{
The Modality of Complete Certainty in Bunin's Novel The Life of Arseniev: Types and Methods of Its Expression
}

\author{
Valentina Ivanovna Kazarina \\ Institute of Philology, Department of Linguistics and Documents Study, Yelets State Bunin University, \\ 39 Kommunarov St., Yelets, 399770, Russian Federation
}

\section{Doi:10.5901/mjss.2015.v6n5s4p55}

\section{Abstract}

\begin{abstract}
The article is devoted to the description of sub-modes of complete certainty about evaluation of the informative component, revealed in the content structure of utterances. The article also covers the ways of their objectification in Bunin's novel The Life of Arsenyev. Modality of complete certainty is understood as a kind of non-predicative modality which forms 'the external modal frame'. It is accepted that markers of complete certainty are modal parentheses, whose functioning conditions and lexical meaning allowed the author to single out certain sub-modes, taking into account the degree of evaluation certainty: 'absolute certainty', 'expected certainty', 'certainty, determined by the thinking process of the modal subject', 'certainty, formed by the knowledge of society'. The markers of absolute certainty are parentheses of the following synonymic set: surely, in fact, really, certainly, undoubtedly, it is true, obviously and predominantly certainly, as well as the lexical unit I repeat. The sub-mode of 'expected certainty' is objectified by the introductory words it is known, clearly, consequently. The sub-mode of 'certainty based on an individual's thinking process' is represented by the lexemes think, remember and sentences in the position of parenthesis I think, I suppose. The level of evaluation certainty depends on whether or not the modal subject takes into account the features characterizing the subject of predication. Apart from the function of evaluation objectifier of complete certainty in the novel, the text-building function of the parentheses really, in fact and undoubtedly has also been emphasized.
\end{abstract}

Keywords: external modal frame, complete certainty, modality, modal subject, sub-mode, subject of the predicate.

\section{Introduction}

\subsection{Introducing the problem}

The questions of determining the status of modality and its semantics are of constant researching interest not only to philosophers-logicians, but also to linguists, who focus on semantics of the sentence, which is determined by the intention of the speaker to communicate something to his/her interlocutor (the reader) as well as its structure.

\subsection{Importance of the problem}

Despite the fact that this phenomenon has long been studied in Russian grammar as one of the components of sentence semantics, in which "the meaning of the sentence lies", according to Bally's theory, many of the issues that determine the status of modality in the organization of the meaningful structure of an utterance still remain a point of debate. Among them there is the external modal frame, its components and their objectification by the lexical content of positional utterance schemes, in particular, by introductory constructions, the study of which dates back to the works of F.I. Buslaev, A.Kh. Vostokov, A.M. Peshkovsky, A.A. Shakhmatov, L.V. Shcherba; V.V. Vinogradov made a considerable contribution to the development of introductory words as markers of modality, and his theory is developed by A.V. Bondarko, G.A. Zolotova, V.B. Kasevich, V.G. Kolshanskiy, V.Z. Panfilov, S.N. Tseitlin, I.B. Shatunovskiy and others. The problems of sentence modality are the subject of research for Immanuel Kant Baltic Federal University's school of thought, headed by professor S.S. Vaulina.

Studying the types of true modality based on the works of one author allows raising the issue of one of the components of the author's individual style.

\section{Method}

Within the meaningful structure of an utterance two constituent components: informative and modal, can be singled out. 
The informative component is its substantial meaning which correlates with the marked proposition. The modal component or modality is considered to be evaluation of the informative component of an utterance. V.V. Vinogradov characterizes it as one of "the basic and primary language categories" (Vinogradov, 1975) in expressing which "the meaning of a sentence only lies" (Bally, 2005). Ivan Meshchaninov refers modality to the "conceptual categories", which "convey a linguistic concept within a certain social environment. These concepts are not described by language, but can be revealed in it, in its lexis and grammar...". "Being formally revealed in syntax and morphology, they become grammatical notions" (Meshchaninov, 1978).

Modality is a complex problematic category of the Russian sentence which is of permanent researching interest to scholars drawing their attention to the types of modal semantics, the debatable character of which determines the rationale behind the research into the types of Russian modality.

Since modality is viewed as a linguistic category, it can be differentiated into predicative and non-predicative. Predicative modality, which is referred to as the "objective" one in syntax, indicates the correlation between the content of the sentence and the extra-linguistic world, the character of the objective connection between the subject and the predicate which are reflected in its content, the connection being fixed primarily by the mood forms of the verb, identifying them as real or unreal. Predicative modality is the essential attribute beyond which the sentence does not exist as a communicative unit. This approach to predicative modality, excluding its termination, is generally accepted.

Non-predicative modality is an assessment of how adequately an extra-linguistic element of the world marked by the utterance is reflected in the mind of the modal subject. By "overlapping" predicative modality (Vinogradov, 1975), it enriches the proposition of the utterance with the corresponding modal semes.

In terms of its semantics and objectification, non-predicative modality is not homogeneous and is divided into modality of potentiality and modality of certainty.

Potentiality is the basis of motion and development of the real world (Philosophic Dictionary, 1963). Its modifiers, included in a positional scheme, establish connections between the predicate and its subject, forming "an internal modal framework of utterance" (Kasevich, 1988): "You are a dangerous man!", she told me, "l'd rather perish in the woods under the knife of an assassin than under your tongue... (Lermontov, A Hero of Our Time). I must now give some explanations of the reasons which have induced me to betray to the public the inmost secrets of a man whom I never knew. (Lermontov, A Hero of Our Time)

In grammar, non-predicative modality of certainty usually means the modality which is represented by the speaker's evaluation of the information component of an utterance, its dictum. Modal evaluation has gnoseological nature. It is determined by the level of knowledge of the modal subject and the level of its awareness of the utterance content. "Knowledge is the result of the process of understanding reality, which is proved by practice, adequate reflection of objective reality in human consciousness" (Gorskii, 1991).

Undoubtedly, the formation of knowledge (cognitive process) happens step by step. Each stage of cognition brings into the mind of homo sapiens new elements which enrich the completeness of knowledge and lead to the formation of more profound and genuine knowledge. The staged character of the cognitive process is reflected on the information reliability level, which is received from the author (the speaker), allowing to regard modal evaluation of certainty as problematic and genuine.

Being connected with neither the predicative axis of the sentence and, consequently, with predicative modality, nor with the inner syntactic non-predicative modality, it forms another layer which overlaps the existing modal component of an utterance representing its inner syntactic modality. Objectifiers of this modal component are parenthetical constructions of introductory character, particles and, sometimes, exclamations which are included into the positional scheme of an utterance, forming its external modal framework (Kasevich, 1988). The speaker, the author of an utterance is the modal subject. This person may or may not coincide with the subject of predication.

The aim of this research is to discover specific features of parenthetical constructions of complete certainty in terms of their functioning in Bunin's novel The Life of Arseniev as one of possible traits of the author's individual style.

\section{Results}

The modality of complete certainty of the given novel is represented by 73 utterances, including the following modal parentheses: in fact, it is true, really, I think, of course, certainly, I repeat, it is clear, it is true, for sure, so and 26 statements with parentheses of the source of the message.

Taking into account the level of confidence in the modality of complete certainty the following sub-modes can be singled out: 'complete or absolute certainty', 'expected certainty', 'certainty based on an individual's thinking process', 'certainty passed on with the knowledge of society'. 
3.1. The sub-mode of 'absolute certainty' about the reliability of information objectifies the synonymic set of the sememe of 'assurance': surely, in fact, really, certainly, undoubtedly, it is true, obviously and predominantly certainly (Aleksandrova, 2010; The Dictionary of Synonyms of the Russian language, 1971), as well as the parenthesis / repeat.

The predominant parenthesis is the most numerous in its functioning (40 examples). The case when the modal subject coincides with the subject of the utterance is represented by 11 examples (approx. 27.5\%), there are also 11 cases when they do not coincide (approx. $72.5 \%$ ).

In case the subject of predication coincides with the modal one, it is marked by a personal pronoun: What did we want it all for? Were we hungry? No, of course not, but during that meal we communed unawares with the earth, with all that sensuous, material substance of which the world is made; Of course, I had often seen myself in a mirror before, but without remembering, without noticing it;

In case the modal subject does not coincide with the bearer of the predicative features, the latter is represented by people who do not participate in the dialogue and are usually marked by pronouns, characterized by the author from memory according to their internal or external features: She looked, of course, very motley in her bright-red-and-yellow rags, and all the time she gently swung her hips, telling me the usual silly stuff, throwing away the kerchief from her small jet-black head, and tormenting me, not only with her hips, with the dreamy sweetness of her lips and eyes, but also with her antiquity, redolent of distant lands,... Lika, dear, but what happens next? You know my attitude towards him; he is, of course, a dear, and I understand that you have fallen... But what happens next? In the evening other guests came too, and we all, except the grown-ups, decided naturally to go around to the neighboring manors as mummers...now and then I feel a pang in my heart at the sight of my mother or Baskakov, who of course felt the same at seeing me; but at once I would cheer myself by saying, "It won't be for some time yet". The use of a personal pronoun in the 2 nd person singular in the position of the subject of the utterance is predetermined by the specific features of rendering other people's speech and addressing the interlocutor: "Look here, my dear friend, you realize, of course, that the whole affair has been an open secret for some time..."

More rarely the bearer of predicative features is represented by

- concrete personal nominates: And father who, certainly, could not but feel his false role of a former, rich man, was nevertheless content with this screaming and ordered to wait; Rehearsals were managed by a professional, unemployed actor, certainly imagining himself to be a big talent, revelling in his destable stage experience...;

- names of towns / residential places and references to them: Certainly, it (the city) couldn't save material historical monuments in such conditions; And suddenly I found myself asking whether it was really true that I was going to join a paper called The Voice to take up a job? In this too, of course, there was something terribly attractive, something called editorial offices and printers;

- events, represented by folded propositions: These feelings were displayed superficially, of course. Outwardly my life went on, of course, in the workaday way. "And in general don't distress yourself overmuch", he (father) added, trying to speak with his usual briskness. "I don't mean, of course, the horse, but your position in general".

- names of insects: And all night long, besides, I was of course devoured by bedbugs (small ones, particularly venomous, which darted boldly off the pillow as soon as I struck a match).

- The subject can be represented implicitly: Of course, I was told what that house was, and who the man was; it was from father and mother that I learnt of the existence in the world of that particular class of people called criminals, convicts, thieves, murders.

In the generative register, the bearers of evaluation of complete certainty are situations: Everybody is driven by some idea. And, of course, nobody knows what exactly it is. "University is certainly a good idea", the doctor replied.

In positional schemes this modifier takes different positions. At the beginning of the sentence (or as a predicative unit) and before the predicative it points to absolute certainty of the proposition: As to mother, of course, I noticed and understood her before all the others...; How dreadful was the beginning of that life! The mere fact of it being my first evening in town, the first after parting from my mother and father, the first in the solitude and, besides, in new and poverty-stricken surroundings, in two cramped rooms, among people absurdly unfamiliar and alien to me, whom, I gentleman's son, naturally regarded as beneath me...

However, certain evaluation might not correlate with the content of the proposition, the positional scheme of which includes a modifier. Thus in the position after a rhetorical question, being included in the ensuing speech segment, the modifier confirms the complete certainty of information, contained in the question: What did we want it all for? Were we hungry? No, of course not, but during that meal we communed unawares with the earth, with all that sensuous, material 
substance of which the world is made.

Placed in pre- or post-position to other components of the scheme, the modifier emphasizes on them, stressing their existence, their complete certainty: I set off, of course, not "the other day" - at first it was necessary to collect at least some money for travelling ...; I replied that I did not know why ... and then, of course, in order to consult seriously at last, what I was going to do about myself.

The modal evaluation of the predicate or its attribute is represented by parceled constructions: And with whom I so rapidly fall in love? With everything, of course: with that young female society to which I was so suddenly introduced; Generally speaking, pride sounded more often than not in what Rostovtsev said. Pride in what? In the fact, of course, that the Rostovtsevs were Russians, genuine Russians, that they lived the especially simple and outwardly modest life that was the real Russian life, and that which there was and could be nothing better...; My brother felt utterly confused when he told me about it: "Forgive me for hiding it even from you, I didn't and still don't want our family to know about it... The point is I am married .....Not legally, of course "

Certainty which corresponds to reality and absolute assurance about it is marked in the novel by non-productive parentheses really ( 3 utterances) and in fact ( 2 examples). Their position in positional schemes is fixed: they are in postposition to the proposition which they characterize. The construction containing them gives reasons for modal evaluation. I joined them, also extremely glad, in the hope of getting home with them, and truly, they at once offered me a lift. Father would say to mother, "The children are leaving our house!" In fact, Nikolay has already left it, and George was going to do it - the period when he was under the parents' care was coming to an end; I was the only one left; it was my turn now...

In dialogues, complete certainty about evaluation is represented by the lexical unit true or its equivalents in the meaning of 'in fact'. However, as a rule, in the text of the novel this modifier is a mark of the sub-mode of 'perhaps' with a fair degree of uncertainty: "And there is the Bibikov lady driving. She is coming to our parts, to Uvarov. He told me the other day that he was expecting her for a stay, and he haggled over a sheep to slaughter ... Another one took it up: "True, it's her" Compare: Then I would wander about, thinking of the books I had read, of the people walking and driving fast, of their all probably being nearly happy and calm in their own way...; What did it matter if Kursk turned out to be just a dreary country town, and dusty Putivl still drearier!

The parenthesis it is true/in truth (4 examples) in combination with the intensifying particle and or without it is a marker of absolute certainty about the information conveyed and it is stylistically marked (spoken) (the lexical meaning of 'indeed, it is so'), ... he (father), in truth, spent his days in that happy idleness, which was then so characteristic not only of the life of country gentlemen, but of Russian life in general...; Before each ball I lived through cruel moments - I had to wear the tails that had belonged to Avilova's deceased husband - completely new, it is true, seemingly never worn, yet they cut me to the quick. Introductory words of course and no doubt (3 examples each) bring the seme of 'categoricalness' to the sememe of complete confidence, which excludes even the slightest degree of doubt in the truthfulness of the stated facts. The parenthesis naturally is stylistically marked (spoken). The modal subject may or may not coincide with the subject of predication: And he turned out to be a really unhappy man ... in a word, he turned out to belong to that dreadful species of Russians which, of course, I came to understand properly only later, in my mature years; Our cousin was married to Pisarev, and for many years we had not been to her house - old Pisarev, her father-inlaw, was, in contrast to his son, a man of extremely serious disposition, with whom my father naturally very soon quarreled; The bitter lot of Pila and Sysoyka? No doubt, reading about it, he (brother) shed tears more than once. The verbal form I repeat (6 examples) in the position of parenthesis is introduced with the purpose of intensifying the truthfulness of evaluation. In the position of the subject of predication the following items appear to be modally evaluated

- propositions of a different status: Yet, on the whole, I repeat, my early childhood appears to me only as a string of summer days...; He (Baskakov) was, I repeat, an excellent storyteller, impersonating his characters with gestures and swift changes of voice. The scope of my boyish observations was very limited, yet what I then observed was, I repeat, typical.

- and persons, coinciding or not coinciding with the modal subject, which are represented by different case forms. Compare: I was born and grew up, as I said, in absolutely open countryside such as cannot even be imagined by a European. Ideas were all very well; but in those youthful revolutionaries, as I said, how much was there also of the mere longing for gay idleness under the cloak of hectic activity ...

3.2. The submode of 'expected certainty' is represented by the parentheses naturally (3 examples), consequently, everyone knows (according to one utterance) and the construction to be honest. The expected certainty is the result of obviousness, clarity of the situation and does not cause any doubt: By his occupation he was a "kulak", but he didn't naturally regard himself as such ...; I am also, if I may say so, a poet. I even published a book once. Now I have naturally given up the lyre - no time, and my talent turned out to be minimal ...; His name was Baskakov; he came from a wealthy 
and noble family; he was clever and gifted, and consequently, could have lived, if not better, at least not worse than many others; But, as everyone knows, there is nothing more dangerous than an excess of confidence in that (destiny). Also, let me say it is quite frankly: what do you have in common? Glikeria is a pretty girl and, to be honest, quite changeable ...

3.3. The submode of 'certainty based on an individual's thinking process' is objectified by the introductory lexical units think, remember and the sentences I think, I suppose in the meaning of 'I think so'. The position of a modifier is not fixed: it is represented

- in preposition to the predicative: "And anyway, I suppose, you can't serve: you have different aspirations"; I remember finding this very touching;

- in post-position to the evaluated proposition: And still it was him, I thought ...; "How do I now come out to tea?", I thought. "And anyway what should I do now? Nothing, I thought, nobody knows about it and nobody will ever know. And everything is ok and l'm doing pretty well"

- or to one of its components: Until then, I think, my mother's traits prevailed in my character, but at that time I started developing my father's ones very fast.

3.4. The speaker's reference to the knowledge and beliefs, typical of the language environment of a society and being the basis for the correlative sub-mode of 'certainty, passed by the knowledge of society' can also refer to the markers of certainty of modal assessment with the seme of 'truth'. The specific feature of this evaluation is the fact that it frees the modal subject of responsibility for the level of truthfulness or does not guarantee absolute certainty in its correctness, although the semes of 'uncertainty' do not contain it either $(26.3 \%$ of all examples with the modality of real evaluation). Parentheses, correlating with verbs and syntactic constructions are also markers of the source.

The introductory word say is the most productive in this function (approx. 10\% of all corresponding structures) in different morphological forms and syntagms: it is said (it was said), as they say - with no fixed place in a positional scheme. As a rule, a modifier is placed in pre-position to the predicative, the source of evaluation is the language environment of the modal subject: he (tatar prince) is said to be chastised by the miraculous icon of Our Lady which is still to be found in the most ancient of our churches, standing above the river just opposite Argamach - that ancient image before which burn undying icon-lamps ...;One evening the herd boys who used to bring up the working horses from the field dashed at full speed into the courtyard of the manor, shouting that Senka had tumbled with his horse at full gallop into the Gap, right to the bottom, into that terrible undergrowth where, it was said, there was something like a slimy funnel. ... she (Glikeria), as they say, is not a suitable match for you ...; I don't want either to sacrifice myself for the people, or to serve them, or to play, as the father says, at district meetings. That's what I can't do either ... Parenthesis performs the same function in post-position to the information component: It was not for nothing that he was thin, stooping, hook-nosed, dark-faced, "like a devil", it was said. I felt that my father was right - "one cannot live like a weeping willow", life was "after all, an excellent thing", as he (father) would sometimes say when drunk; and already I saw consciously that there really was something irresistibly wonderful in verbal creation.

The source of information lies in the following:

- data from history and mythology: And how often did I climb with Baskakov to the attic where, tradition said, some saber of Grandfather of Great-grandfather was lying about? The town itself boasted of its antiquity, as it was fully entitled to do so: it is indeed one of the most ancient Russian towns, situated amid the wide blackearth fields of the Sub steppe, at that fatal line beyond which there once stretched "wild, unknown lands"; and in the days of the principalities of Suzdal and Ryazan it had been one of the principal bulwarks of Russia, which, according to the chroniclers, were the first to take the impact of the storm, the dust, and the cold from severe Asian clouds which, now and then, would hang over them, were the first to see the sky aflame with the terrible fires they kindled by day and night, the first to forewarn Moscow of imminent calamity, the first also to lay down their lives for her; You spread yourself too far away, as the oracle books put it.

- groups of people or their individual representatives, objectified by different constructions: And then the famous Stanovliansky hollow. The main road descended, near Stanovaya, into a fairly deep ravine, and this place invariably inspired an almost superstitious terror in any belated traveler, at any time of the year when he passed through it; and more than once in my youth I myself had felt that purely Russian terror when passing near Stanovaya; So Nekrasov, for instance, is not a poet to your mind, is he? Granted that, as my father put it, he was an "eternal student" but, after all, he was an Arseniev.

To make a reference to other people's words, the introductory word say is used in a stylistically deflated style (spoken). It is found in the words of other people, who are representatives of peasantry: The first time the debtor failed to pay on time, the tradesman reminded him politely. One more failure to pay and he warned him, "See, here, don't forget a third time, or else l'll wipe off my mark - what shame that will bring you then!" Yes, afterwards I learned that Rostovtsev 
was far from being the only one to hold forth like this; time and again I heard those feignedly humble assertions - we, people said, are simple folk, even our tsar Alexander Alexandrovich wears tarred boots ...; "Of course, of course", the peasant said, obviously thinking thoughts of his own. "I only meant to say that everybody's selling nowadays, bad days have come to the gentry"

Full certainty about the content of a dialogue is marked by a particle which is homonymous to an introductory word: And glancing at me he squinted still more. "What about you? You aren't selling yet?" "That's my father's business", I replied evasively. "Of course, of course", the peasant said, obviously thinking thoughts of his own. "I only meant to say that everybody's selling nowadays, bad days have come to the gentry"

Apart from the function of an objectifier of complete certainty, modal modifiers and particles are also text-forming components of a syntactic whole: There's nothing to think about. Of course, you need to serve, to get a position...; Nosily we disguised ourselves as best we could, mostly as peasants - my hair was curled tightly, my face rouged and powdered, a small black moustache painted with burnt cork - and we thronged out onto the porch, before which, in darkness, some sleighs were already standing; we took our seats, laughing and shouting to the accompaniment of the bells and swiftly whisked off, cutting through the fresh snowdrifts. And, naturally, I turned out to be in the same sleigh with Annchen...; 0 , how wonderful everything is - that wild inhospitable night in the fields, and this friendly, evening life in the town, those peasants and townsfolk drinking and eating, all that old provincial Russia with its coarseness, strength, domesticity, and my hazy dreams of some fairy St. Petersburg, of Moscow, of famous writers, and the fact that I, too, am about to have a good drink, and to set to with a wolf's appetite on the cabbage soup and the soft, white, city bread! Indeed, I ate and drank such a lot that afterward... I sat for a long time hatless on the porch steps...; Was my childhood sad for some particular reason? The fact, for instance, that I grew up amid great solitude? Don Quixote and the knights' castles were succeeded by seas, frigates, Robinson Crusoe, the world of ocean and tropics. To that world I had unquestionably belonged at some time.

\section{Discussion}

In Bunin's novel, the modality of complete certainty is represented by sub-modes which are divided into 'absolute certainty', 'expected certainty', 'certainty, determined by the mental activity of the modal subject', 'certainty created by the knowledge of society'. The novel is specifically a literary auto-biographical recollection of the author's early days, which predetermines the prevailing absolute certainty about the truthfulness of the message which is communicated irrespective of the fact whether or not the modal subject (author) coincides with the subject of the proposition of the utterance (the bearer of the predicative feature). The lexical unit certainly is the most frequently used parentheses in the text. The seme of 'categoricalness' of true evaluation is marked by the parentheses undoubtedly and definitely. The text-building function of the modal modifier has also been emphasized.

The mode of true evaluation is sporadically represented by the unit certainly.

\section{References}

Aleksandrova, Z. E. (2010). Slovar sinonimov russkogo yazyka. [The Dictionary of Synonyms of the Russian language]. - Moscow: Drofa. [in Russian]

Bally, Ch. (2001). Obshchaya lingvistika i voprosy frantsuzskogo yazyka. [General linguistics and French language issues] Transl. from French. - Moscow: Editorial URSS. [in Russian]

Bunin, I. A. (1952). Zhizn Arsenieva [Bunin, I. A. The Life of Arseniev]. New York, NY: The Chekhov publishing house. Retrieved from http://lib.ru/BUNIN/buninars.txt [in Russian].

Rozental, M. M., \& Yudin, P. F. (1963). Filosofskiy slovar. [A Dictionary of Philosophy]. -Moscow: Political Literature. [in Russian]

Gorski, D. P., Ivin, A. A., Nikiforov, A. L. (1991). Kratkiy slovar po logike. [A Concise Dictionary of Logic] - Moscow: Prosveshchenie. [in Russian].

Kasevich, V. B. (1988). Semantika. Sintaksis. Morfologiya. [Semantics. Syntax. Morphology]. - Moscow: Nauka. Retrieved from http://www.twirpx.com/file/471848. [in Russian].

Meshchaninov, I. I. (1978). Chleny predlozheniya i chasti rechi. [Sentence parts and parts of speech[. - Moscow: Nauka. [in Russian].

Evgenieva, A. P. (1971). Slovar sinonimov russkogo yazyka. [The dictionary of synonyms of the Russian language[. - Leningrad: Nauka. [in Russian].

Vinogradov, V. V. (1975). O kategorii modalnosti i modalnykh slovakh $v$ russkom yazyke. Izbranniye raboty. Issledovaniya po grammatike russkogo yazyka [About the category of modality and modal words in the Russian language. Selected works. Studies in Russian grammar]. - Moscow: Nauka. [in Russian]. 